Diabetologia 7, 405-408 (1971)

(c) by Springer-Verlag 1971

\title{
ORIGINALS
}

\section{Observations on Heredity and Obesity in the Emergence of Diabetes}

\author{
W.P.U. Jafkson, G.D. Campbelt, M.D. Goldberg and N.Marine \\ Endocrine Research Group, University of Cape Town and Medical Research Council, and the Diabetes Clinic, King \\ Edward VIII Hospital and University of Natal, South Africa
}

Received: May 17, 1971, accepted: August 4, 1971

Summary. The 899 offspring of Natal Indian diabetic couples are compared with the general Indian population. Diabetes was present in $25 \%$ of offspring aged $40-49$ as against $14.7 \%$ of the general population. The ratio of offspring diabetics to population diabeties diminished with age, suggesting that the genetic influence affects mainly age of onset of diabetes. "Old" and "young" diabetic couples had a similar proportion of diabetic children. Another similar comparison could be made between an inbred Tamil Indian family in Cape Town and the general population of Cape Hindus. More young diabetics were obese than old diabetics, in 3 different racial groups and in both "clinic" and "survey" diabetics, whereas in the general population obesity is more common over age 40. Overweight may be a more important diabetes risk factor in young than in old people.

Observations sur l'hérédité et l'obésité dans l'apparition du diabèté

Résumé. 899 enfants nés de couples Indiens diabétiques (province du Natal) ont été comparés à l'ensemble de la population indienne. Le diabète était présent chez $25 \%$ des descendants âgés entre 40 et 49 ans contre $14.7 \%$ pour la population générale. La différence de prévalence du diabète entre les descendants des couples diabétiques et la population générale diminuait avec l'âge, ce qui semble indiquer que le facteur génétique affecte surtout l'âge d'apparition du diabète. La proportion d'enfants diabétiques était identique pour les couples diabétiques jeunes ou vieux. Cette même comparaison a pu se faire entre une famille indienne Tamil dont les membres s'épousent entre eux et vivant au Cap et l'ensemble de la population indienne du Cap. La prévalence d'obésité était plus grande chez les diabétiques jeunes que chez les dia. bétiques âgés dans trois groupes raciaux différents et ceci aussi bien pour le diabète symptomatique qu' asymp- tomatique; par contre l'obésité est plus fréquente pour la population générale dépassant l'âge de 40 ans. L'obésité semble jouer un rôle plus important comme facteur diabétogène chez les jeunes que chez les personnes âgées.

Beobachtungen über Erblichkeit und F'ttleibigkeit beim Auftreten des Diabetes.

Zusammenfassung. Eine Gruppe von 899 Indern aus Natal, Nachkommen diabetischer Elternpaare, wurde mit der indischen Gesamtbevölkerung in Natal verglichen. Diabetes wurde in $\mathbf{2 5} \%$ der Nachkommen im Alter zwischen 40 und 49 Jahren beobachtet, verglichen mit $14.7 \%$ in der Gesamtbevölkerung. Die Verhältniszahl: Diabetiker unter den Nachkommen zu den Diabetikern in der Gesamtbevölkerung verringerte sich mit ansteigendem Alter; dieser Befund scheint anzudeuten, daß ein möglicher genetischer Faktor einen besonderen Einfluß auf das Alter ausübt, in dem der Diabetes sich manifestiert. "Alte" und ,junge" Elternpaare hatten eine ähnliche zahlenmäßige Verteilung diabetischer Kinder. Ein ähnlicher Vergleich konnte zwischen einer Familiengruppe indischer Tamilen in Kapstadt und der gesamten HinduBevölkerung von Kapstadt angestellt werden. Bei drei rassisch verschiedenen Bevölkerungsgruppen und bei ",klinischen" wie bei ,neuentdeckten" Diabetikern wurde festgestellt, daß Fettleibigkeit häufiger bei jungen als bei alten Diabetikern auftrat, während in der Gesamtbevölkerung die Fettleibigkeit im Alter von über 40 Jahren häufiger war. Übergewicht ist als Risikofaktor für den Diabetes vielleicht wichtiger bei jüngeren als bei älteren Personen.

Key words: Offspring of diabetic couples, age and heredity in diabetes, obesity, population studies, diabetes prevalence.
Diabetes mellitus causes floundering among geneticists. We clinicians cannot tell them whether hyperglycaemia per se means diabetes, whether "idiopathic diabetes" is one or more diseases, whether all or only a fraction of diabetes is hereditary, whether it is the same disease in different races and which of the different manifestations of the diabetic syndrome are inherited. Furthermore, we believe that people may inherit the diabetic genetic predisposition yet never develop diabetes, either because they die too young or because environmental factors prevent its expression.

This paper attempts to provide a little more data that may be of some interest.

\section{The findings}

Connubial Offspring. Among the many diabetic Indians in Durban we had traced 152 husband and wife diabetic pairs and 899 of their offspring up to 1966 [5]. Ascertainment was through one or other parent, and the term "diabetic" here means the overt, clinical disease. For various reasons we were unable to confirm the presence of diabetes in both members of all the pairs by actual measurement of blood glucose, and the same applies to the diaboties among their children ("connubial offspring"). The diabetes is thus "reputed" rather than "proven" in some cases. 
During the same period of time, a diabetes prevalence study involving 2427 Indians in the Durban area was performed, providing us with knowledge concerning already known diabetes and previously unrecognized diabetes, diagnosed at our survey[2]. ${ }^{1}$ Table 1 compares the prevalence of reputed diabetes

Table 1. Known diabetes among connubial offspring (899) and Indian survey population (2427) (in percentages)

\begin{tabular}{lcc}
\hline Age group & Offspring & Indian population \\
\hline $10-19$ & 0.7 & 0.0 \\
$20-29$ & 3.5 & 0.3 \\
$30-39$ & 10.5 & 1.4 \\
$40-49$ & 14.5 & 4.8 \\
$50-59$ & $41^{\mathrm{a}}$ & 7.0 \\
$60-69$ & - & 10.0 \\
All ages & 6.5 & 1.8 \\
\hline
\end{tabular}

a Less than 10 subjects.

among the connubial offspring with known diabetes among the Indian community.

In Table 2 the diabetic couples are divided into "old" and "young" after the criteria of Cooke and co- hyperglycaemia. The great majority of their offspring underwent oral glucose tolerance tests - 332 in all. In Table 3 we compare the total prevalence of diabetes (known plus discovered) in the offspring with the total prevalence among the Indian population on survey. (Methods and interpretations as previously described

Table 3. Total diabetes (known + discovered) among connubial offspring (332) and Indian survey population (2427) (in percentages)

\begin{tabular}{lcc}
\hline Age group & Offspring & Indian population \\
\hline $10-\mathbf{1 9}$ & 7.1 & 0.7 \\
$20-29$ & 5.6 & 0.9 \\
$30-39$ & 19.4 & 7.2 \\
$40-49$ & 25.0 & 14.7 \\
$50-59$ & - & 20.6 \\
$60-69$ & - & 24.5 \\
$70+-$ & - & 31.3 \\
All ages & 13.3 & 6.0 \\
\hline
\end{tabular}

$[4,6])$. It may be observed that the ratio of diabetes prevalence among offspring to prevalence among population diminishes with age, as diagrammatically shown in Fig. 1.

Table 2. Offspring of diabetic couples (Natal Indians)

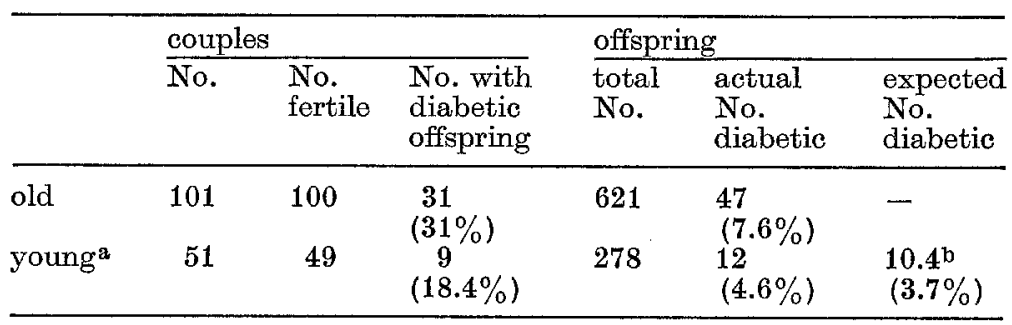

a At least one parent under 40 at diagnosis (criterion of Cooke et al., 1966).

b Caloulated using offspring of old parents as the standard and correcting for differences in age distribution.

workers [1] - "young" when at least one parent was under age 40 at the time of diagnosis of diabetes. The "old" and "young" couples appear equally fertile. Offspring of the "old" couples had more diabetes than offspring of the "young" couples, but were themselves older. Age correction indicates a slightly, but insignificantly, lower frequency of diabetes among the offspring of the "old" couples (see last 2 columns of Table 2).

We then went further and accepted only those families in whom the presence of diabetes in the parents could be verified by the demonstration of diagnostic

$190 \%$ of all subjects over 10 years of age living in one village were screened by blood and urine glucose estimation two hours after $50 \mathrm{~g}$ of oral glucose. Those who showed glycosuria or whose blood glucose exceeded 109 $\mathrm{mg}$ per $100 \mathrm{ml}$ had full glucose tolerance tests. A final diagnosis of "discovered diabetes" was made if 2 of the 3 estimations on blood taken while fasting, at $1 \mathrm{~h}$ and $2 \mathrm{~h}$ exceeded 120,185 and $140 \mathrm{mg}$ per $100 \mathrm{ml}$ respectively (venous plasma, Autoanalyzer, Hoffman method).
A Tamil "Family". During studies among Indians living in Cape Town (of whom the total is only around 9000 as against half a million in Natal) we found a

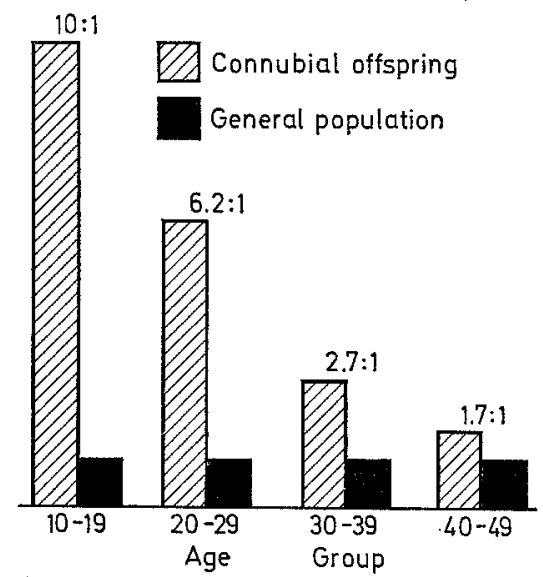

Fig. 1. Ratio of diabetes in connubial offspring to diabetes in Indian population with age 
high prevalence of diabetes in one area (Rylands Estate). Thirty-eight per cent over age 25 were diabetic; one third of these already under treatment. It then transpired that all the inhabitants in this area could be considered as one big family of Tamilian Hindus, with several first and second cousin marriages and uncleniece marriages.

At the same time we were investigating other Hindu Indian populations [6], and Fig. 2 shows a comparison between known, discovered and total diabetes among the Tamil family and the Indian population.

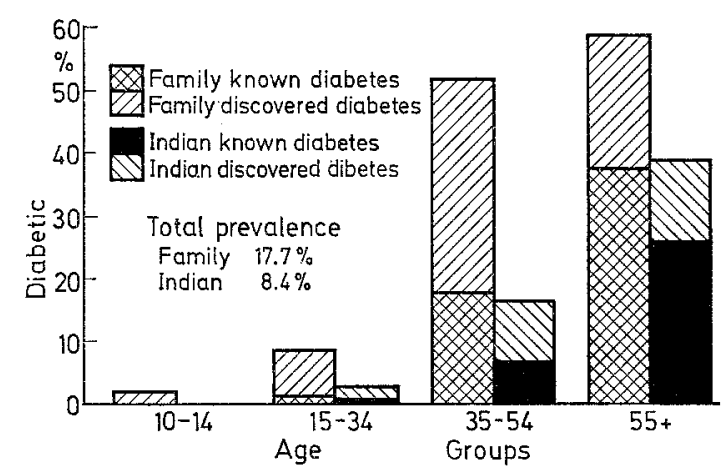

Fig. 2. Diabetes prevalence in Tamil family (311) and Cape Indian population (830)

Body Weight. In none of our population studies have we found any positive correlation between screening values of blood glucose and body weight, yet in all of them diabetes itself appeared to be closely related to weight $[2,6,3]$. Among the Natal Indians the prevalence of diabetes was $1.9 \%$ among those less than $85 \%$ of their standard weight, ${ }^{2}$ rising to $17.8 \%$ in those
Cape-coloured diabetics discovered at survey. On the other hand, in all three races in the non-diabetic population, more people over 40 were obese than under 40. These findings are briefly shown in Table 4 . In this Table only women are included (because of the small number of males) except in the coloured group which includes both sexes. Only non-diabetic Indians are shown, but a similar ratio between the two age groups is present among the non-diabetics of all races examined. The difference between obesity rates in "old" and "young" diabetics is statistically significant.

\section{Discussion}

Several previous reports on the children of diabetic couples have appeared $[1,9,11,8,10]$, and the prevalence of diabetes in these children has been around $5 \%$ in most of them. In the largest series known to us, from Roumania, $28 \%$ of 1173 offspring were diabetic [7]. Among our 899 Indian offspring the frequency of clinical diabetes $(6.6 \%)$ was in keeping with most reports in white communities, but from our data we could go further and report the total diabetes prevalence among 332 offspring $(13.3 \%)$, in comparison with that of the general Indian population $(6.0 \%)$. The difference between the connubial offspring and the general population was really greater than these figures indicate because of the youth of the offspring, and comparisons are best made between matched age groups. Incidentally, the offspring were no more overweight than the population.

With increasing age the difference in diabetes prevalence between offspring and population diminishes

Table 4. Obesity in "young" and "old" diabetics (showing percentage obese)

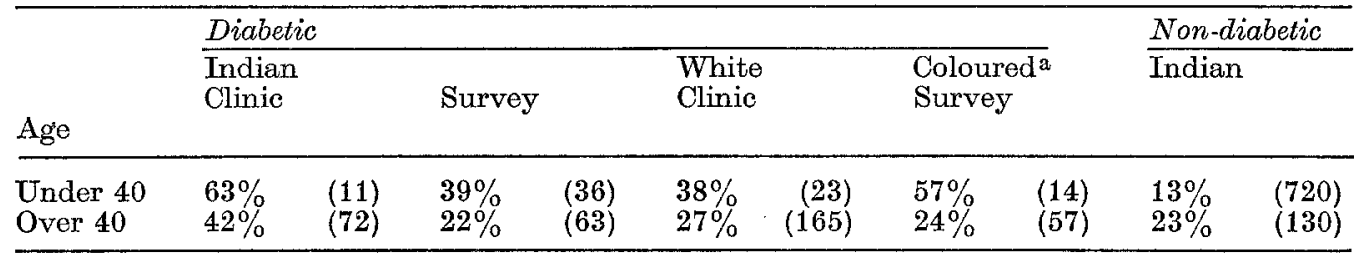

Figures in brackets indicate total number in each group.

a Both sexes included, only women in other groups. Difference between percentage obesity in all diabetics under 40 and all diabetics over $40=45 \%-28.5 \%=16.5$. Standard error of difference $=5.75 ; p<0.01$.

more than $25 \%$ overweight [3]. The difference was less among Cape Bantu; and Bantu women, who were enormously more fat than men, had less diabetes [6].

On analysis of our Indian studies we observed that more young (under age 40) diabetics were obese (over $15 \%$ above standard weight) than old diabetics. We analysed our figures further, and found that the same applied to Indian established diabetics attending a clinic, to white clinic diabetics in Cape Town and to

\footnotetext{
2 On Documenta Geigy tables.
}

from $10: 1$ to $1.7: 1$ (Fig. 1). This change in ratio with age is again seen when the large, consanguineous Tamil family is compared with a similar Indian population in Cape Town (Fig. 2), and has been noted by Cooke et al.from British data [1]. It would seem then that the total potential for diabetes is little different between connubial offspring and the general population, but that the main effect of inheritance is to influence its age of onset. Such observations would seem to fit most readily with the theory of multifactorial genetic influence. 
Cooke and co-workers [1] divided their diabetic couples into "young" (at least one parent under age 40 at time of diagnosis of diabetes) and "old". They found no difference in fertility between young and old couples, but their young couples had a significantly higher proportion of offspring who were diabetic. Our own considerably larger figures do not show any difference and do not support the suggestion that inheritance is of greater importance in diabetes of earlier onset. It should, however, be noted that diabetes among the Indian is in some ways different from that among white people - especially in the virtual absence of insulin-dependence, even in adolescents.

The frequency of diabetes among the inbred Tamil family indicates the importance of genetic influence, but does not help to distinguish the type of inheritance concerned. It must make one cautious of accepting prevalence rates of small communities as indicating more than the effects of isolation and inbreeding, assuming that there was a high concentration of the diabetic genes in the few progenitors of the group under consideration.

That obesity was more common among diabetics under 40 than over 40 was surprising to us, but was found in all groups analyzed (Table 4), whereas among each corresponding general population obesity was more frequent over the age of 40 . This suggests that overweight may be a more important environmental factor in producing hyperglycaemia and diabetes in young people than in older people. In the past we may have missed this because of our tendency to be preoccupied with the ketosis-prone type of diabetes in younger people.

Acknowledgements. We gratefully acknowledge the help of medical colleagues (especially Dr. Victor Major), technical staff and lay assistants too numorous to mention. We are grateful to Professor Alan Emery for his comments. This work represents part of the programme of the joint University of Cape Town/South African Medical Research Council Endocrine Research Group and was also in part supported by the United States Public Health Service grant number AM 09052. Much of the contents of this paper was communicated at the 7 th Congress of the International Diabetes Federation in Buenos Aires, August 23-28, 1970.

\section{References}

1. Cooke, A.M., Fitzgerald, M.G., Malins, J.M., Pyke, D.A.: Diabetes in children of diabetic couples. Brit. med. J. 1966 II, 674-677.

2. Goldberg, M.D., Marine, N., Ribiero, M. B., Campbell, G.D., Vinik, A.I., Jackson, W.P.U.: Prevalence of glycosuria and diabetes among Indians and Bantu. S. Afr. med. J. 43, 733-738 (1969).

3. Jackson, W.P.U., Goldberg, M.D., Marine, N., Vinik, A.I.: Effectiveness, reproducibility, and weight-relation of screening-tests for diabetes. Lancet 1968 I, $1101-1105$.

4. - Vinik, A.I., Joffe, B.I., Sacks, Amy, Edelstein, Isobel.: Vicissitudes encountered in a diabetes population study. S. Afr. med. J. 44, 1283-1287 (1970).

5. - Goldberg, M.D., Marine, N., Keller, P., Campbell, G.D., Vinik, A.I.: Potential diabetics, in Diabetes (Editor J. Ostman), Proc. 6th Congress of the International Diabetes Federation, Stockholm, 1967, pp. 486-497. Amsterdam: Excerpta Med. Found. 1969.

6. Marine, M., Vinik, A.I., Edelstein, Isobel, Jackson, W.P. U.: Diabetes, hyperglycemia and glycosuria among Indians, Malays and Africans (Bantu) in Cape Town, South Africa. Diabetes 18, 840-857 (1969).

7. Pavel, I., Piepta, R.: Ereditatea in Diabet. Editura Academiei Republicii Socialiste Romania, 1968.

8. Post, R.D.: An approach to the question, does all diabetes depend upon a single genetic locus? Diabetes 11, $56-65(1962)$.

9. Pincus, G., White, P.: On the inheritance of diabetes mellitus. III. The blood sugar values of the relatives of diabetics. Amer. J. Med. Sci. 188, 780-782 (1934).

10. Simpson, N.E.: Multifactorial inheritance. A possible hypothesis for diabetes. Diabetes 13, 462-468 (1964).

11. West, K.M.: Response to cortisone in prediabetes. Glucose-steroid-glucose tolerance in subjects whose parents are both diabetic. Diabetes $9,379-385$ (1960).

W.P.U. Jackson, M.D.

University of Cape Town

Dept. of Medicine

Medical School

Cape Town, South Africa 